There is no doubt that open heart surgery is not as safe as we think it is.

While I agree with the possible causal mechanisms suggested by the authors for the development of neurological damage after open heart surgery, there is an additional factor which potentially may aggravate neurological damage-namely, hyperglycaemia or dextrose infusion. There is now ample evidence from animal experiments that hyperglycaemia ${ }^{12}$ and possibly dextrose infusion ${ }^{3}$ at the time of cerebral ischaemia/anoxia markedly diminish the chances of recovery from any neurological damage caused.

Given the authors' evidence of frequent postoperative neurological dysfunction, and the fact that we have shown that it is possible safely to perform open heart surgery without appreciable hyperglycaemia and in the absence of peroperative dextrose infusion ${ }^{4}$ I would suggest that there is enough evidence that cardiopulmonary bypass pump priming fluids that do not contain glucose should be used, and that glucose containing fluids should be infused with extreme caution during open heart surgery.

Hospital for Sick Children,

London WCIN 3JH

1 Siemkowicz E. Hyperglycaemia in the reperfusion period hampers recovery from cerebral ischaemia. Acta Neurol Scand 1981;64:207-16.

2 Pulsinelli WA, et al. Moderate hyperglycaemia augments ischaemic brain damage. A neuropathologic study in the rat. Neurology 1982;32:1239-46.

3 Lainer WL, et al. Effects of IV dextrose and head position on neurologic outcome after complete cerebral ischaemia. Anesthesiology 1985;63(3A):A110.

4 McKnight CK, Elliott MJ, Pearson DT, Holden MP, Alberti KGMM. The effect of four different crystalloid bypass pump priming fluids upon the metabolic response to open-heart surgery. I Thorac Cardiovasc Surg 1985;9:97-111.

SIR,-In their admirable and detailed prospective study of early neurological complications of coronary artery bypass surgery Dr Pamela J Shaw and her colleagues found a large number and variety of problems (16 November, p 1384) but these should not be regarded as a comprehensive list.

Sudden sensorineural hearing loss with tinnitus is well recognised after cardiopulmonary bypass but is uncommon, an incidence of 1 in 1000 operations having been suggested..$^{1-3}$ It is therefore perhaps not surprising that no cases were encountered by Dr Shaw and others, although in this department we have seen two such patients in the past four months. Lesser degrees of hearing loss might be more easily missed without specialist investigation. A prospective study, with pure tone audiometry before and after operation, recorded a loss of $>10 \mathrm{db}$ in 9 out of 68 patients (13\%) and a smaller loss in a further 36 patients. ${ }^{4}$ About half these individuals had partial recovery; in none was recovery complete. The possible causes proposed for both severe unilateral sensorineural hearing loss and these lesser degrees are similar to those discussed by Dr Shaw.

Clinicians dealing with patients after cardiac surgery should be aware of the possibility of significant hearing loss and consider referral for specialist assessment if necessary.

SIMON BAER

VICTORIA MOORE-GILLON Department of Otolaryngology, St George's Hospital,

London SW17

1 Arenberg IK, Allen GW, De Boer A. Sudden deafness immediately following cardiopulmonary bypass. $\mathcal{F}$ Laryngol Otol 1972;86:73-7.

2 Wright JLW, Saunders SH. Sudden deafness following cardiopulmonary bypass surgery. $\mathcal{F}$ Laryngol Otol 1975;89:757-9.

3 Plasse HM, Spencer FC, Mittleman M, Frost JO. Unilateral sudden loss of hearing, an unusual complication of cardiac operation. J Thorac Cardiovasc Surg 1980;79:822-6.
Shapiro MJ, Purn JM, Raskin C. A study of the effects of cardiopulmonary bypass surgery on auditory function. Laryngoscope 1981;91:2046-52.

\section{Cyanide toxicity and the hazards of dicobalt edetate}

SIR,-The article by Drs C Dodds and C McKnight concerned itself with one aspect of cyanide toxicity. It contained an exceedingly important point, that of the patient's cyanosis, which unfortunately passed without comment. The medical division of the Health and Safety Executive was concerned with this case at factory level and the following points should be made to explain this cyanosis.

The blood cyanide concentration on admission to hospital was substantial. In cyanide toxicity there is poisoning of the cytochrome oxidase system, which is responsible for transfer of oxygen at tissue level. The arterial blood can therefore be full of oxygen but it cannot be used, resulting, paradoxically, in tissue anoxia. In this case the initial $\mathrm{PO}_{2}$ was very high. Because of the high partial pressure of oxygen in the arterial blood, the patient with cyanide toxicity characteristically has a red appearance.

In this case, as stated in the article, the patient was cyanosed on arrival at hospital. First aid procedures were initiated literally on the factory floor. The patient had been hauled out of the cyanide bath, laid prone on the adjacent walkway, Holger Neilson artificial respiration started, and the cyanide emergency kit summoned from nearby. The safety officer who carried out these measures then crushed two ampoules of amyl nitrite under the patient's mouth and nose while continuing the artificial respiration. An ambulance was called.

Amyl nitrite causes a methaemoglobinaemia. Methaemoglobin "mops up" cyanide. A substantial methaemoglobinaemia causes a cyanotic appearance. When the patient arrived at hospital the likely cause of the "cyanosis" was methaemoglobinaemia, which was probably responsible for the delivery of a live patient to hospital - the methaemoglobin having "mopped up" sufficient cyanide to prevent instant death.

The safety officer's prompt first aid was, it seems, life saving and thus most notable. The place of amyl nitrite in cyanide toxicity, which can be used safely and easily by the layman, must not be forgotten

Finally, the article comments "that dicobalt edetate [should] be used only in severe cases when patients do not respond to repeated doses of thiosulphate and nitrites because it is dangerous," as it proved so to be in this case. The numerical measurement of blood cyanide concentrations includes the cyanide bound to the methaemoglobin. It is a moot point, but all the free cyanide might have been converted to cyanomethaemoglobin, the absence of free cyanide thus rendering the dicobalt edetate especially toxic.

Health and Safety Executive

William G Pickering

Medical Division

Gosforth,

Tyne and Wear

\section{Treatment of homozygous familial} hypercholesterolaemia

SIR,-Dr Richard West and his colleagues (19 October, p 1079) have rightly pointed out that patients with homozygous familial hypercholesterolaemia are usually resistant to treatment and that results with various types of treatment are usually disappointing.

Implementation of aggressive treatment at younger age, before the development of cardiovascular complications, is extremely important in these patients, and an end to side portacaval shunt may be performed in those patients who fail to respond to medical treatment. It has been postulated that the hepatrophic effect of insulin might regulate to some degree the production of cholesterol by the liver and that shunting of pancreatic venous blood away from the liver would reduce the production of cholesterol by the liver. ${ }^{1}$ However, portacaval shunts have not restored normal serum cholesterol values.

We are also treating a family with this disorder. Both parents have the heterozygous form of hypercholesterolaemia and are asymptomatic. Of the five children, two sisters, aged 15 and 11 years, have homozygous familial hypercholesterolaemia with serum cholesterol values of $26 \mathrm{mmol} / \mathrm{l}(987 \mathrm{mg} / 100$ $\mathrm{ml})$ and $17 \mathrm{mmol} / \mathrm{l}(642 \mathrm{mg} / 100 \mathrm{ml})$ respectively. The three other children have the heterozygous form of hypercholesterolaemia.

The elder of the two girls with the homozygous condition presented with xanthomas and did not have cardiac symptoms. An electrocardiogram was normal. Echocardiography showed a large left ventricular cavity with normal left ventricular function. Coronary angiography was not done. She was not taking any treatment and was eating a normal diet. She was given dietary advice and an indigenous drug (gugul) known to lower serum cholesterol values as she could not afford to buy medicines. With six months of treatment there was no fall in serum cholesterol level.

An end to side portacaval shunt was performed. She did not develop hepatic encephalopathy. On discharge from hospital her serum cholesterol value was $13 \mathrm{mmol} / 1(520 \mathrm{mg} / 100 \mathrm{ml})$. After six months' follow up the xanthomas had decreased in size, serum cholesterol ranged from 12 to 13 $\mathrm{mmol} / 1$ (450-500 $\mathrm{mg} / 100 \mathrm{ml})$, and she remained asymptomatic, with a patent portacaval shunt.

S K SHARMA RAKESH KaUSHAL T K CHATTOPADHYAY

Departments of Medicine and Surgery,

All-India Institute of Medical Sciences,

New Delhi 110029 India

1 Starzl TE, Putnam CE, Porter KA, et al. Portal diversion for the treatment of glycogen storage disease in humans. Ann Surg 1973;108:525-39.

\section{Cardiopulmonary resuscitation}

SIR,-Drs Richard O Cummins and Mickey C Eisenberg (16 November, p 1401) must consider that damage caused by overenthusiastic resuscitation by members of the public may be greatly under-reported because of the medical profession's reluctance to discourage well meaning attempts to help by the unskilled. The following three cases, which happened in the past 10 years in different hospitals, were not reported because there were alternative (and less distressing) explanations for what happened.

Case 1 -A young man in his 20 s collapsed while visiting his wife in hospital. Despite attempts by visitors and hospital staff to revive him, he died and was certified as having succumbed to a coronary thrombosis. When the collapse occurred the maternity nurses were away at supper and were not prepared mentally or materially to cope with such an emergency. It is at least possible that this young man fainted under the emotional stress of seeing his new child and died of respiratory obstruction because nobody took the simple initiative of securing a clear airway.

Case 2-A miner of 40 collapsed with severe chest pain at the beginning of the morning shift. 